\title{
The Current Status of Corporate Social Responsibility Activities in Thailand: Evidence from Listed Companies in the Stock Exchange of Thailand
}

\author{
Chitphinan Charoenrungrueang and Mullika Sungsanit
}

\begin{abstract}
The purpose of this research was to investigate the current implementation status of corporate social responsibility activities of a set of companies listed on the Stock Exchange of Thailand. Specifically, we applied a multi-dimensional framework, which developed from the evolution of Porter and Kramer's thought on the relationship between business and society, to analyze the types of corporate social responsibility activities and to explore the issues addressed. The research adopted qualitative and quantitative document analysis on sustainability reports from a sample of 20 listed companies which were the winners of Thailand Corporate Social Responsibility Awards in 2014. The findings revealed that the implementation of corporate social responsibility activities was based on generic issues and value chain social impacts rather than social needs. In addition, the types of corporate social responsibility activities were philanthropy and responsive CSR rather than strategic philanthropy, strategic CSR and CSV. Therefore, companies should shift towards strategic CSR and CSV which related to the strategy and operations of any specific company or the places in which they operate because they can be a source of opportunity, innovation, and competitive advantage. Then, an important next step should be to study how to motivate CSV practices and how to transform the corporate social responsibility activities of companies from CSR to CSV.
\end{abstract}

Index Terms-Creating shared value, corporate social responsibility, current status, Thailand.

\section{INTRODUCTION}

Managing the relationship between business and society has been one of the main topics in academic and business literature for a long time [1]. Porter and Kramer [2] have proposed a new interpretation for this relationship based on the mutual dependence which was defined as "Creating Shared Value (CSV)". They [2] describe that CSV involves creating economic value in a way that also creates value for society by addressing its needs and challenges. Hence, CSV is more effective and far more sustainable than the traditional concepts of corporate social responsibility (CSR) [2].

Porter and Kramer's thought on the relationship between business and society suggested that CSV is thelast step of the evolution [2]. Porter and Kramer [3] proposed strategic

Manuscript received March 28, 2016; revised July 6, 2016.

The authors are with the School of Management Technology, Suranaree University of Technology, Nakhon Ratchsima, Thailand (e-mail: chompunuch13@gmail.com, mullika@g.sut.ac.th). philanthropy since 2002, which suggested that companies can use their charitable efforts to improve their competitive context. They [4] have also proposed the link between competitive advantage and corporate social responsibility since 2006, which categorized CSR into two groups, namely; responsive CSR and strategic CSR. Thismovement has led businesses to take a more strategic perspective and to benefit financially from the creation of social value simultaneously [5].

In Thailand, CSV is an emerging trend and has received attention from both the public and private sectors. In practice, many companies still focused on the tension between business and society rather than on their interdependence. Furthermore, CSR was rested on a generic rationale that does not tie to strategy and operations of the company. The survey of Srisuphaolarn [6] on the pattern of CSR development in Thailand indicated the CSR practices surrounding social and environmental issues, which are less relevant to the business' core activities. However, the previous studies on CSR activities focused only on the altruistic to strategic CSR continuum. Whereas, the investigation of CSR activities from philanthropy to CSV, as the evolution of Porter and Kramer's thought, is relatively new and gaining much attention.

Therefore, the purpose of this research was to investigate the current implementation status of CSR activities in a set of companies that are listed on the Stock Exchange of Thailand. We applied a multi-dimensional framework to analyze the types of corporate social responsibility activities and to explore the issues addressed. Hence, research questions include:

1) What are the types of CSR activities companies implementing?

2) What are the patterns of CSR activities companies implementing?

3) What are the social issues of CSR activities companies addressing?

\section{LITERATURE REVIEW}

\section{A. Corporate Philanthropy and Strategic Philanthropy}

Corporate philanthropy has assumed a central role in the development of CSR since the beginning as shown in periods being examined [7]. Schwartz [8] defined it as "a one-way flow of resources from a donor to a done, a flow voluntarily generated by the donor though based upon no expectation that a return flow, or economic quid pro quo, will reward the act". Fry, Keim and Meiners [9] defined it as "a transfer, of a charitable nature, of corporate resources to recipients at 
below market prices". Godfrey [10] defined it as "an unconditional transfer of cash or other assets to an entity or a settlement or cancellation of its liabilities in a voluntary nonreciprocal transfer by another entity acting other than as an owner".

Based on the given definitions, Gautier and Pache [11] defined corporate philanthropy as "voluntary donations of corporate resources to charitable causes". Therefore, corporate philanthropy can be defined as a voluntary giving of corporate to charitable causes with no direct link to business activity such as donations, sponsorship, and volunteering.

However, Porter and Kramer [3] indicate that most corporate philanthropy is diffused and unfocused. They [3] proposed "a strategic philanthropy" as strategic giving addressing important social and economic goals simultaneously, targeting areas of competitive context where the company and society both benefit because the firm brings unique assets and expertise. Porter and Kramer [3] suggested that a company's competitive context includes factor conditions, demand conditions, context for strategy and rivalry, and related and supporting industries. Therefore, strategic philanthropy involves using philanthropy to improve the elements of competitive context.

In conclusion, the differentiating point between corporate philanthropy and strategic philanthropy is a convergence of corporate philanthropy and shareholder interests [3].

\section{B. Corporate Social Responsibility}

Porter and Kramer [4] proposed the link between competitive advantage and corporate social responsibility. They [4] suggested that the traditional school of thought on corporate social responsibility (CSR) focus on the tension between business and society rather than on their interdependence and the company's CSR activities were not tied to the strategy and operations, or the places in which it operates.

They [4] introduce a new way suggested that CSR can be much more than a cost, a constraint, or a charitable deed. It can also be a source of opportunity, innovation, and competitive advantage. Thus, Porter and Kramer [4] categorize CSR into two categories: i.e., responsive and strategic CSR.

Responsive CSR emphasizes inside-out linkages and responds to generic social issues, value chain's impacts. It comprises of two elements that are acting as a good corporate citizen and mitigating the harm arising from a firm's value chain activity [4]. Porter and Kramer [4] suggested that a good corporate citizen is attuned to the evolving social concerns of stakeholders and mitigating existing or anticipated adverse effects from business activities. As a result, many companies mitigated the harm arising from a firm's value chain activities by using standardized sets of social and environmental or establishing the best practices.

Strategic CSR, on the other hand, emphasizes inside-out linkages and outside-in linkages. It also responds to value chain social impacts and social dimensions of competitive context. Hence, a company can choose a unique position by doing things differently from competitors in a way that lowers the costs or better serves a particular set of customer needs [4].

\section{Creating Shared Value}

Scholars adopted different definitions of Shared Values. The definitions of shared value can be divided into two groups. The first group uses the definition by Porter and Kramer and the second group defines shared value in terms of creating value on different types of stakeholders [12]. While the origins of all the definitions based on the Porter and Kramer's concept [12].

This research adopted Porter and Kramer's concept [2], which is defined as "policies and operating practices that enhance the competitiveness of a company while simultaneously advancing the economic and social conditions in the communities in which it operates". There are three distinct ways to do this. Firstly, company can reconceive products and markets that focus on society's needs. There are the unmet needs of the global economy where the company can tap into. This way shared value is created when demand for products and services meet societal needs [2].

Secondly, company can redefine productivity in the value chain. A company's value chain can affect and is affected by numerous societal issues. Porter and Kramer [2] suggest that there are five ways companies can redefine productivity in the value chain; i.e., 1) redefining energy use and logistics, 2) resource use, 3) procurement, 4) distribution, and 5) employee productivity. Shared value is therefore created when societal problems can increase yield and cost savings in the firm's value chain and occur the congruence between societal progress and productivity in the value chain.

Thirdly, companies can enable local cluster development. It has been widely recognized that the success of every company is affected by the supporting companies and infrastructure around it [2]. Therefore, the company could create shared value by building clusters to improve company productivity while addressing gaps or failures in the conditions surrounding the cluster [2]. The ways of creating shared value which modified from Porter and Kramer's concept are summarized in the Table I.

TABLE I: THE WAY OF CREATING SHARED VALUE

\begin{tabular}{|c|c|c|c|}
\hline The ways & Focus on & Economic value & Social value \\
\hline First & $\begin{array}{l}\text { Society's needs } \\
\text { (Unmet needs) }\end{array}$ & $\begin{array}{l}\text { New customers } \\
\text { New markets }\end{array}$ & $\begin{array}{l}\text { Serving } \\
\text { disadvantaged } \\
\text { communities }\end{array}$ \\
\hline Second & $\begin{array}{l}\text { Value chain } \\
\text { (Productivity) }\end{array}$ & $\begin{array}{l}\text { Cost reduction } \\
\text { New distribution } \\
\text { New location }\end{array}$ & $\begin{array}{l}\text { Solving societal } \\
\text { problems and } \\
\text { societal progress }\end{array}$ \\
\hline Third & $\begin{array}{l}\text { Cluster } \\
\text { (Collaboration) }\end{array}$ & $\begin{array}{l}\text { Transparent } \\
\text { markets } \\
\text { Partners }\end{array}$ & $\begin{array}{l}\text { Improving } \\
\text { clusters }\end{array}$ \\
\hline
\end{tabular}

Source: modified from Porter and Kramer (2011).

Adopting Porter and Kramer's framework, this research classifies the types of corporate social responsibility activities into five categories: philanthropy, strategic philanthropy, responsive CSR, strategic CSR, and CSV.

\section{Social Issue}

Porter and Kramer [4] divide social issues into three categories; i.e., generic social issues, value chain social impacts, and social dimensions of competitive context.

Generic social issues can be defined as social issues 
which may be important to society but are neither significantly affected by the company's operations nor influence company's long-term competitiveness [4].

Value chain social impacts are social issues which are significantly affected by the company's activities in the ordinary course of business [4].

Social dimensions of competitive context are factors in the external environment that significantly affect the underlying drivers of competitiveness in those places where the company operates [4].

In addition, in terms of creating shared value, Porter and Kramer [2] propose that society's needs are the greatest unmet needs of the global economy. In advanced economies, demand for products and services that meet societal needs is rapidly growing which can be seen in the social enterprise movement in Europe and America.

In conclusion, following Porter and Kramer suggestion, this research classifies social issues companies addressing into three categories: generic social issues, value chain social impacts which include social issues are affected by the company's activities and affected the underlying drivers of competitive context, and societal needs.

\section{Methodology}

\section{A. Research Design and Sampling}

The research adopted qualitative and quantitative document analysis on sustainability reports from a sample of 20 listed companies which were the winners of Thailand Corporate Social Responsibility Awards in 2014.

Based on the evolution of Porter and Kramer's thought on the relationship between business and society, we developed a multi-dimensional framework that incorporated types, patterns, and issues. This multi-dimensional framework was empirically applied through a document analysis on sustainability reports which was an appropriate research method to analyze the types of corporate social responsibility activities and to explore the issues addressed in reporting.

The 20 cases were purposefully sampled to cover a mix of size, industries, and geographies because insights from multiple cases were considered to be more robust and convincing and the external validity can be increased [13].

\section{B. Data Collection and Analysis}

The research was carried out in the following manner. The data were collected from sustainability reports on web sited of listed companies and the Stock Exchange of Thailand. Then, we analyzed sustainability reports which were the secondary data. However, sustainability reports are said to be representative of the corporate attitude towards sustainability and have been identified as being advantageous over e.g. interviews with corporate representatives because they ensure to get the corporate perspective and priorities on sustainability rather than a single manager's perspective and priorities [13].

The reports were read line-by-line. Text sections that describe corporate social responsibility activities were assigned to the types, patterns, and issues addressed. Descriptive statistics of CSR coding were analyzed using
Excel.

\section{RESUlts}

\section{A. Profile of the Sample}

The samples included 11 large listed companies and 8 small listed companies. Large companies were in group 1, which had market capitalization more than 50,000 million Baht. Small companies were in group 4, which had a market capitalization between 2,000-10,000 million Baht.

Demographic information is illustrated in Table II below.

TABLE II: PROFILE OF THE SAMPLE

\begin{tabular}{llll}
\hline \hline \multirow{2}{*}{ Awards } & & Group 1 & Group 4 \\
\hline CSR Award & SET Awards of Honor & 3 & 1 \\
\cline { 2 - 4 } & The best & - & 1 \\
\cline { 2 - 4 } & Excellent & 5 & 4 \\
\hline CSR & Most Improved CSR & 1 & 1 \\
\cline { 2 - 4 } Recognition & Rising Star & 2 & 1 \\
\hline \hline
\end{tabular}

\section{B. The Implementation of CSR Activities}

This research classified the types of corporate social responsibility activities into five categories: philanthropy, strategic philanthropy, responsive CSR, strategic CSR, and CSV.

The findings revealed that companies performed several types of CSR activities. The proportions of CSR activities implemented by all selected companies were the responsive CSR (46 percent), philanthropy (28 percent), strategic CSR (12 percent), CSV ( 9 percent), and strategic philanthropy (5 percent) respectively. Information is illustrated in Table III and Fig. 1 below.

TABLE III: THE TYPES OF CSR ACTIVITIES

\begin{tabular}{lllll}
\hline \hline Types & \multicolumn{2}{c}{ CSR activities } & $N$ & Percent \\
\hline & $\begin{array}{l}\text { Large } \\
\text { companies }\end{array}$ & $\begin{array}{l}\text { Small } \\
\text { companies }\end{array}$ & & \\
\hline $\begin{array}{l}\text { Philanthropy } \\
\text { Strategic }\end{array}$ & 42 & 69 & 111 & $28 \%$ \\
Philanthropy & 11 & 7 & 18 & $5 \%$ \\
Responsive CSR & 122 & 60 & 182 & $46 \%$ \\
Strategic CSR & 33 & 16 & 49 & $12 \%$ \\
CSV & 24 & 11 & 35 & $9 \%$ \\
\hline Total & 232 & 163 & 395 & $100 \%$ \\
\hline \hline
\end{tabular}

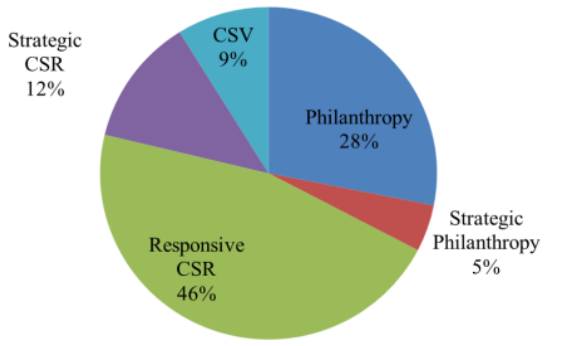

Fig. 1. The types of CSR activities.

The findings also indicated that large companies tend to focus on responsive CSR activities, while small companies still focus on philanthropic activities. Information is illustrated in Table III. 
The findings about the area of focus of CSR activities companies carried out are as follows.

\section{1) Philanthropy}

The issues that companies focused on are education, quality of life, and environment issues. There were three patterns the companies implement philanthropic activities which included donations, sponsorship, and volunteering. The popular philanthropic activity was donation for education. Information is illustrated in Table IV and Fig. 2 below.

TABLE IV: THE IMPLEMENTATION OF PHILANTHROPY

\begin{tabular}{lllll}
\hline \hline Issues & \multicolumn{2}{c}{ Patterns } & & $N$ \\
\hline Education & Donation & Volunteering & Sponsorship & \\
Quality of Life & 8 & 6 & 2 & 33 \\
Environment & 7 & 15 & 6 & 29 \\
Health Care & 7 & 17 & 3 & 27 \\
Others & 0 & 5 & 4 & 16 \\
\hline Total & 47 & 44 & 5 & 6 \\
\hline \hline
\end{tabular}

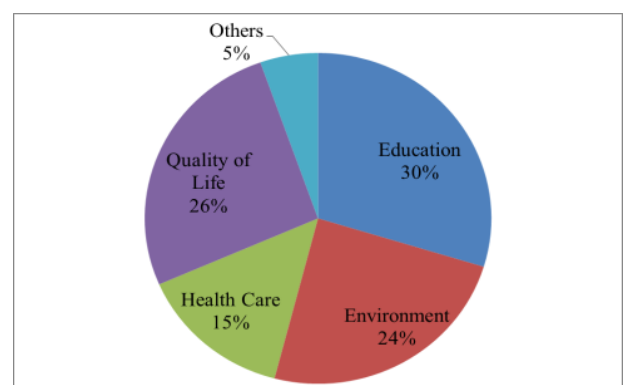

Fig. 2. The implementation of philanthropy.

When comparing the issues of philanthropic activities which large and small companies focus on, the result indicated that the large companies focus their philanthropic activities on quality of life, while small companies focus on education. Information is illustrated in Table V and VI below.

\begin{tabular}{lllll}
\multicolumn{5}{c}{ TABLE V: THE PHILANTHROPIC OF LARGE COMPANIES } \\
\hline \hline Issues & \multicolumn{1}{c}{ Patterns } & N \\
\hline \multicolumn{1}{c}{ Donation } & Volunteering & Sponsorship & \\
\hline Quality of Life & 1 & 6 & 5 & 12 \\
Education & 8 & 2 & 0 & 10 \\
Environment & 2 & 6 & 2 & 10 \\
Health Care & 5 & 3 & 2 & 10 \\
Others & 0 & 0 & 0 & 0 \\
\hline Total & 16 & 17 & 9 & 42 \\
\hline \hline
\end{tabular}

\begin{tabular}{|c|c|c|c|c|}
\hline \multirow[t]{2}{*}{ Issues } & \multicolumn{3}{|c|}{ Patterns } & \multirow[t]{2}{*}{$N$} \\
\hline & Donation & Volunteering & Sponsorship & \\
\hline Education & 17 & 4 & 2 & 23 \\
\hline Environment & 5 & 11 & 1 & 17 \\
\hline Quality of Life & 7 & 9 & 1 & 17 \\
\hline Health Care & 2 & 2 & 2 & 6 \\
\hline Others & 0 & 1 & 5 & 6 \\
\hline Total & 31 & 27 & 11 & 69 \\
\hline
\end{tabular}

\section{2) Strategic philanthropy}

The companies adopted strategic philanthropy type focused their activities mostly on health care, quality of life, and education issues respectively. There were two patterns the companies implement their strategic philanthropic activities to improve a competitive context; i.e., to improve 1) factor conditions and 2) demand conditions. The most implemented activities of strategic philanthropy were using philanthropy to improve factor conditions on education. Information is illustrated in Table VII and Fig. 3 below.

TABLE VII: THE IMPLEMENTATION OF STRATEGIC PHILANTHROPY

\begin{tabular}{|c|c|c|c|c|}
\hline \multirow[t]{2}{*}{ Issues } & \multicolumn{2}{|c|}{ Patterns } & \multirow[t]{2}{*}{$N$} & \multirow[t]{2}{*}{ Percent } \\
\hline & $\begin{array}{l}\text { Factor } \\
\text { conditions }\end{array}$ & $\begin{array}{l}\text { Demand } \\
\text { conditions }\end{array}$ & & \\
\hline Health Care & 3 & 3 & 6 & $33 \%$ \\
\hline Quality of Life & 3 & 2 & 5 & $28 \%$ \\
\hline Education & 4 & 0 & 4 & $22 \%$ \\
\hline Environment & 3 & 0 & 3 & $17 \%$ \\
\hline Total & 13 & 5 & 18 & $100 \%$ \\
\hline
\end{tabular}

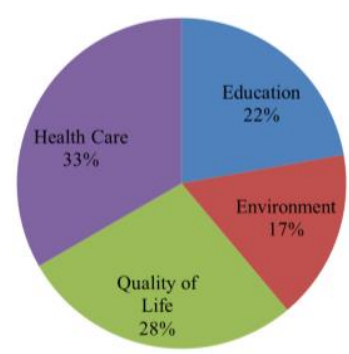

Fig. 3. The implementation of strategic philanthropy.

When comparing the issues that large and small companies focus upon, the result indicated that the large companies focused their strategic philanthropic activities on quality of life, while small companies focused on health care. Information is illustrated in Table VIII and IX below.

\begin{tabular}{|c|c|c|c|c|}
\hline \multirow[t]{2}{*}{ Issues } & \multicolumn{2}{|c|}{ Patterns } & \multirow[t]{2}{*}{$N$} & \multirow[t]{2}{*}{ Percent } \\
\hline & $\begin{array}{l}\text { Factor } \\
\text { conditions }\end{array}$ & $\begin{array}{l}\text { Demand } \\
\text { conditions }\end{array}$ & & \\
\hline Quality of Life & 2 & 2 & 4 & $22 \%$ \\
\hline Health Care & 3 & 0 & 3 & $17 \%$ \\
\hline Education & 2 & 0 & 2 & $11 \%$ \\
\hline Environment & 2 & 0 & 2 & $11 \%$ \\
\hline Total & 9 & 2 & 11 & $61 \%$ \\
\hline
\end{tabular}

TABLE IX: THE STRATEGIC PHILANTHROPIC OF SMALL COMPANIES

\begin{tabular}{lllll}
\hline \hline Issues & Patterns & & $N$ & Percent \\
\hline & Factor & Demand & & \\
& conditions & conditions & & \\
\hline Health Care & 0 & 3 & 3 & $17 \%$ \\
Education & 2 & 0 & 2 & $11 \%$ \\
Environment & 1 & 0 & 1 & $5.5 \%$ \\
Quality of Life & 1 & 0 & 1 & $5.5 \%$ \\
\hline Total & 4 & 3 & 7 & $39 \%$ \\
\hline \hline
\end{tabular}

\section{3) Responsive CSR}

The companies adopted responsive CSR type focused their activities mostly on the environment, quality of life, and safety respectively. There were two patterns of responsive CSR that companies adopted which were a good citizenship and using standardized sets of social and environmental. The most implemented of responsive CSR activities were 1) environmental stewardship as a good citizenship and 2) using standardized sets of environmental. Information is illustrated in Table $\mathrm{X}$ and Fig. 4 below. 
TABLE X: THE IMPLEMENTATION OF RESPONSIVE CSR

\begin{tabular}{lllll}
\hline \hline Issues & \multicolumn{2}{c}{ Patterns } & $N$ & Percent \\
\hline & $\begin{array}{l}\text { Good } \\
\text { citizenship }\end{array}$ & $\begin{array}{l}\text { Mitigate harm } \\
\text { from value } \\
\text { chain activities }\end{array}$ & & \\
\hline $\begin{array}{l}\text { Environment } \\
\text { Quality of }\end{array}$ & 53 & 70 & 123 & $68 \%$ \\
Life & 24 & 0 & 24 & $13 \%$ \\
Safety & 0 & 19 & 19 & $10 \%$ \\
Health Care & 9 & 0 & 9 & $5 \%$ \\
Education & 7 & 0 & 7 & $4 \%$ \\
\hline Total & 93 & 89 & 182 & $100 \%$ \\
\hline \hline
\end{tabular}

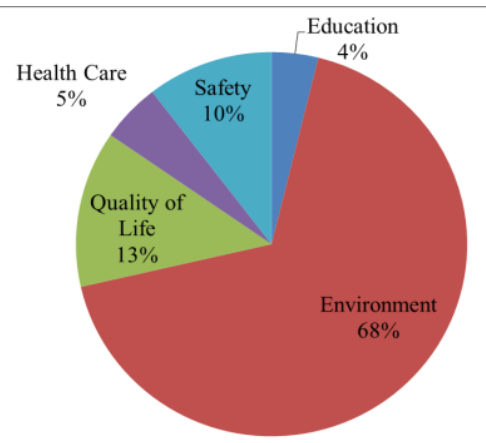

Fig. 4. The implementation of responsive CSR.

The top 3 issues that large companies and small companies concerned about were environment, quality of life, and safety issues. Information is illustrated in Table XI and XII below.

TABLE XI: THE RESPONSIVE CSR OF LARGE COMPANIES

\begin{tabular}{lllll}
\hline \hline Issues & Patterns & & $N$ & Percent \\
\hline & $\begin{array}{l}\text { Good } \\
\text { citizenship }\end{array}$ & $\begin{array}{l}\text { Mitigate harm } \\
\text { from value } \\
\text { chain activities }\end{array}$ & & \\
\hline Environment & 40 & 39 & 79 & $43 \%$ \\
Quality of Life & 16 & 0 & 16 & $9 \%$ \\
Safety & 0 & 13 & 13 & $7 \%$ \\
Education & 7 & 0 & 7 & $4 \%$ \\
Health Care & 7 & 0 & 7 & $4 \%$ \\
\hline Total & 70 & 52 & 122 & $67 \%$ \\
\hline \hline
\end{tabular}

TABLE XII: THE RESPONSIVE CSR OF SMALL COMPANIES

\begin{tabular}{lllll}
\hline \hline Issues & Patterns & & $N$ & Percent \\
\hline & $\begin{array}{l}\text { Good } \\
\text { citizenship }\end{array}$ & $\begin{array}{l}\text { Mitigate harm } \\
\text { from value } \\
\text { chain activities }\end{array}$ & & \\
\hline Environment & 13 & 31 & 44 & $24.2 \%$ \\
Quality of Life & 8 & 0 & 8 & $4.4 \%$ \\
Safety & 0 & 6 & 6 & $3.3 \%$ \\
Health Care & 2 & 0 & 2 & $1.1 \%$ \\
Education & 0 & 0 & 0 & 0 \\
\hline Total & 23 & 37 & 60 & $33 \%$ \\
\hline \hline
\end{tabular}

\section{4) Strategic CSR}

The companies adopted strategic CSR type focused their activities mostly on the environment and health care. Companies transformed value chain activities to benefit society through choosing a unique position by offering products differently from competitors in a way that better serves a particular set of customer needs. In addition, companies leveraged investment to improve salient areas of competitive context. Then, most companies offered the environmentally friendly product. Information is illustrated in Table XIII and Fig. 5 below.
TABLE XIII: THE IMPLEMENTATION OF STRATEGIC CSR

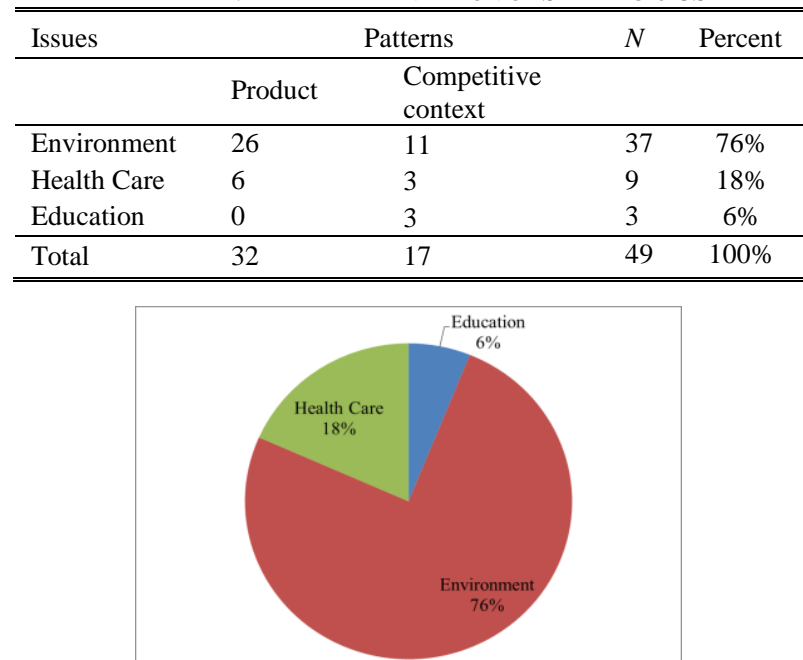

Fig. 5. The implementation of strategic CSR.

When comparing the issues that large and small companies focus upon, the result indicated that they focused their strategic CSR activities on environment and quality of life. Information is illustrated in Table XIV and XV below.

\begin{tabular}{|c|c|c|c|c|}
\hline \multirow[t]{2}{*}{ Issues } & \multicolumn{2}{|r|}{ Patterns } & \multirow[t]{2}{*}{$N$} & \multirow[t]{2}{*}{ Percent } \\
\hline & Product & $\begin{array}{l}\text { Competitive } \\
\text { context }\end{array}$ & & \\
\hline Environment & 18 & 6 & 24 & $49 \%$ \\
\hline Health Care & 3 & 3 & 6 & $12 \%$ \\
\hline Education & 0 & 3 & 3 & $6 \%$ \\
\hline Total & 21 & 12 & 33 & $67 \%$ \\
\hline \multicolumn{5}{|c|}{ TABLE XV: THE STRATEGIC CSR OF SMALL COMPANIES } \\
\hline \multirow[t]{2}{*}{ Issues } & & Patterns & $N$ & Percent \\
\hline & Product & Competitive context & & \\
\hline Environment & 8 & 5 & 13 & $27 \%$ \\
\hline Health Care & 3 & 0 & 3 & $6 \%$ \\
\hline Education & 0 & 0 & 0 & $0 \%$ \\
\hline Total & 11 & 5 & 16 & $33 \%$ \\
\hline
\end{tabular}

\section{5) $C S V$}

The companies adopted CSV type focused their activities on the environment and quality of life issues. However, there was only one way which was redefining productivity in the value chain. There were three patterns that companies had implemented CSV, which included 1) resource use, 2) energy use and logistics, and 3) employee productivity. Information is illustrated in Table XVI, XVII, and XVIII below.

TABLE XVI: THE IMPLEMENTATION OF CSV

\begin{tabular}{lllll}
\hline \hline Issues & \multicolumn{3}{c}{ Patterns } & $N$ \\
\hline & $\begin{array}{l}\text { Resource } \\
\text { use }\end{array}$ & $\begin{array}{l}\text { Energy use } \\
\text { and logistics }\end{array}$ & $\begin{array}{l}\text { Employee } \\
\text { productivity }\end{array}$ \\
\hline Environment & 10 & 22 & 0 & 32 \\
Quality of Life & 0 & 0 & 3 & 3 \\
\hline Total & 10 & 22 & 3 & 35 \\
\hline \hline
\end{tabular}

TABLE XVII: THE CSV OF LARGE COMPANIES

\begin{tabular}{lllll}
\hline \hline Issues & \multicolumn{2}{c}{ Patterns } & $N$ \\
\hline & $\begin{array}{l}\text { Resource } \\
\text { use }\end{array}$ & $\begin{array}{l}\text { Energy use and } \\
\text { logistics }\end{array}$ & $\begin{array}{l}\text { Employee } \\
\text { productivity }\end{array}$ & \\
\hline Environment & 7 & 15 & 0 & 22 \\
Quality of Life & 0 & 0 & 2 & 2 \\
\hline Total & 7 & 15 & 2 & 24 \\
\hline \hline
\end{tabular}


TABLE XVIII: THE CSV OF SMALL COMPANIES

\begin{tabular}{lllll}
\hline \hline Issues & & \multicolumn{1}{c}{ Patterns } & & $N$ \\
\hline & Resource use & $\begin{array}{l}\text { Energy use } \\
\text { and logistics }\end{array}$ & $\begin{array}{l}\text { Employee } \\
\text { productivity }\end{array}$ & \\
\hline Environment & 3 & 7 & 0 & 10 \\
Quality of Life & 0 & 0 & 1 & 1 \\
\hline Total & 3 & 7 & 1 & 11 \\
\hline \hline
\end{tabular}

In summary, CSR activities implemented in companies winning the CSR Award imply that:

1. The companies adopted 1) philanthropy, 2) strategic philanthropy, 3) responsive CSR, 4) strategic CSR, and 5) $\mathrm{CSV}$ in different social and environmental issues. Nevertheless, companies focused their activities mostly on the environment. Information is illustrated in Table XIX and Fig. 6 below.

2. The top 3 issues that large companies concerned about were environment, quality of life, and health care. While small companies were mostly about the environment, quality of life, and education. Information is illustrated in Table XX, and XXI below.

TABLE XIX: THE IMPLEMENTATION OF CSR ACTIVITIES

\begin{tabular}{llllllll}
\hline \hline Issues & $(1)$ & $(2)$ & $(3)$ & $(4)$ & $(5)$ & $N$ & Percent \\
\hline Environment & 27 & 3 & 123 & 37 & 32 & 222 & $56 \%$ \\
Quality of Life & 29 & 5 & 24 & 0 & 3 & 61 & $15 \%$ \\
Education & 33 & 4 & 7 & 3 & 0 & 47 & $12 \%$ \\
Health Care & 16 & 6 & 9 & 9 & 0 & 40 & $10 \%$ \\
Safety & 0 & 0 & 19 & 0 & 0 & 19 & $5 \%$ \\
Others & 6 & 0 & 0 & 0 & 0 & 6 & $2 \%$ \\
\hline Total & 111 & 18 & 182 & 49 & 35 & 395 & $100 \%$ \\
\hline \hline
\end{tabular}

Note: (1) (2) (3) (4) and (5) indicate the types of CSR activities.

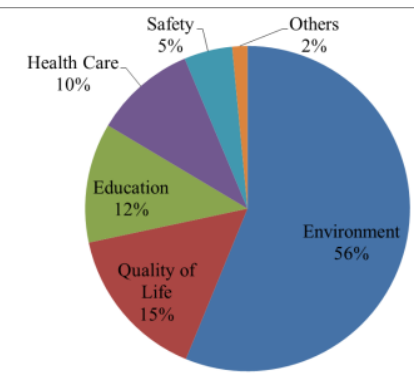

Fig. 6. The implementation of CSR activities.

TABLE XX: THE IMPLEMENTATION OF LARGE COMPANIES

\begin{tabular}{llllllll}
\hline \hline Issues & $(1)$ & $(2)$ & $(3)$ & $(4)$ & $(5)$ & $\mathrm{N}$ & Percent \\
\hline Environment & 10 & 2 & 79 & 24 & 22 & 137 & $35 \%$ \\
Quality of Life & 12 & 4 & 16 & 0 & 2 & 34 & $9 \%$ \\
Health Care & 10 & 3 & 7 & 6 & 0 & 26 & $6.5 \%$ \\
Education & 10 & 2 & 7 & 3 & 0 & 22 & $5.5 \%$ \\
Safety & 0 & 0 & 13 & 0 & 0 & 13 & $3 \%$ \\
Others & 0 & 0 & 0 & 0 & 0 & 0 & $0 \%$ \\
\hline Total & 42 & 11 & 122 & 33 & 24 & 232 & $59 \%$ \\
\hline \hline
\end{tabular}

TABLE XXI: THE IMPLEMENTATION OF SMALL COMPANIES

\begin{tabular}{llllllll}
\hline \hline Issues & $(1)$ & $(2)$ & $(3)$ & $(4)$ & $(5)$ & $\mathrm{N}$ & Percent \\
\hline Environment & 17 & 1 & 44 & 13 & 10 & 85 & $21.5 \%$ \\
Quality of Life & 17 & 1 & 8 & 0 & 1 & 27 & $7 \%$ \\
Education & 23 & 2 & 0 & 0 & 0 & 25 & $6 \%$ \\
Health Care & 6 & 3 & 2 & 3 & 0 & 14 & $3.5 \%$ \\
Safety & 0 & 0 & 6 & 0 & 0 & 6 & $1.5 \%$ \\
Others & 6 & 0 & 0 & 0 & 0 & 6 & $1.5 \%$ \\
\hline Total & 69 & 7 & 60 & 16 & 11 & 163 & $41 \%$ \\
\hline \hline
\end{tabular}

\section{Social Issues}

This research classified social issues companies addressing into three categories; 1) generic social issues, 2) value chain social impacts which include social issues are affected by the company's activities and affected the underlying drivers of competitive context, and 3) societal needs.

For a dimension of social issues addressed, companies were focused more on generic issues and value chain social impact than social needs. The biggest proportion of the activities was on generic issues, while social needs were not being addressed. The CSR activities implemented to address the generic issues focused mainly on the environment and quality of life. On the other hand, CSR activities addressing the value chain social impact focused mainly on the environment and safety. Most CSR activities were done to companies internally and communities surrounded. Information is illustrated in Table XXII below.

TABLE XXII: THE SOCIAL ISSUES ADDRESSING BY CSR ACTIVITIES

\begin{tabular}{lllll}
\hline \hline Social issues & \multicolumn{2}{c}{ CSR activities } & $N$ & Percent \\
\hline & $\begin{array}{l}\text { Large } \\
\text { companies }\end{array}$ & $\begin{array}{l}\text { Small } \\
\text { companies }\end{array}$ & & \\
\hline Generic social issues & 122 & 98 & 220 & $56 \%$ \\
$\begin{array}{l}\text { Value chain social } \\
\text { impacts }\end{array}$ & 111 & 64 & 175 & $44 \%$ \\
Societal needs & 0 & 0 & 0 & $0 \%$ \\
\hline Total & 233 & 162 & 395 & $100 \%$ \\
\hline \hline
\end{tabular}

\section{CONCLUSION}

The purpose of this research is to investigate the current implementation status of CSR activities. In order to do so, we apply a multi-dimensional framework to analyze the types of corporate social responsibility activities and to explore the issues addressed.

The conclusion of this research can describe all research questions. Firstly, results indicate that the companies adopt several types of CSR activities. The proportions of CSR activities implemented by all selected companies are responsive CSR (46 percent), philanthropy (28 percent), strategic CSR (12 percent), CSV ( 9 percent), and strategic philanthropy (5 percent) respectively. Large companies tend to focus on responsive CSR activities, while small companies still focus on philanthropic activities.

However, the implementation of CSR activities is less relevant to the business' core activities. Therefore, companies should shift towards strategic CSR and CSV which related to the strategy and operations of any specific company or the places in which they operate because they can be a source of opportunity, innovation, and competitive advantage.

Secondly, the patterns of CSR activities are different between types of CSR activities. Philanthropic activities emphasize donation. Strategic philanthropic activities emphasize factor conditions. Responsive CSR activities emphasize using standardized sets of social and environmental. Strategic CSR activities emphasize choosing a unique position by offering products differently from competitors such as the environmentally friendly product. CSV activities emphasize redefining productivity in the value chain which includes 1) resource use, 2) energy use and 
logistics, and 3) employee productivity.

However, the patterns of CSR activities still focus on inside-out linkages rather than outside-in linkages such as using standardized sets, developing product, and redefining productivity in the value chain. Therefore, companies should adopt the patterns of CSR activities to outside-in linkages and should adopt the several ways of creating shared value.

Finally, regarding a dimension of social issues addressed, companies' CSR activities addressed more the generic issues and value chain social impact than social needs. The biggest proportion was on generic issues, while the social needs were not yet being addressed. Then, the top issue that large companies and small companies concerned was the environment. Therefore, companies should investigate the social needs.

The findings have implications for both academicians and practitioners. In academia, the findings are expected to help researchers conduct further studies into developing mechanisms which encourage the implementation of CSR activities is more effective and more sustainable. Then, in practice, the findings are expected to help practitioners improve further decisions into strategic level and design processes.

This research is not without limitations. Firstly, the analysis is based on documentary materials; for further investigation, it might be useful to develop in-depth interviews with key figures involved in the implementation of CSR activities. Secondly, the sample size is small and only focuses on large and small companies.

Therefore, the future research should strive to extend the analysis to all size and business models. In addition, the future research should be to study how to motivate CSV practices and how to transform the corporate social responsibility activities of companies from CSR to CSV.

\section{REFERENCES}

[1] L. Michelini and D. Fiorentino, "New business models for creating shared value," Social Responsibility Journal, vol. 8, pp. 561-577, August 2011.

[2] M. E. Porter and M. R. Kramer, "Creating shared value," Harvard Business Review, vol. 89, pp. 62-77, February 2011.

[3] M. E. Porter and M. R. Kramer, "The competitive advantage of corporate philanthropy," Harvard Business Review, vol. 80, pp. 56-68, December 2002

[4] M. E. Porter and M. R. Kramer, "Strategy and society: The link between competitive advantage and corporate social responsibility," Harvard Business Review, vol. 84, pp. 78-92, December 2006.

[5] D. Lee, "From corporate social responsibility to creating shared value with suppliers through mutual firm foundation in the Korean bakery industry: A case study of the SPC group," Asia Pacific Business Review, vol. 20, pp. 461-483, May 2014.
[6] P. Srisuphaolarn, "From altruistic to strategic CSR: How social value affected CSR development-a case study of Thailand," Social Responsibility Journal, vol. 9, pp. 56-75, October 2011.

[7] A. Crane, The Oxford Handbook of Corporate Social Responsibility, 1st ed. New York, U.S.A.: Oxford University Press Inc., 2008, ch. 2, p 23.

[8] R. A. Schwartz, "Corporate philanthropic contributions," The Journal of Finance, vol. 23, pp. 479-497, June 1968

[9] L. W. Fry, G. D. Keim, and R. E. Meiners, "Corporate contributions: Altruistic or for-profit?" The Academy of Management Journal, vol. 25, pp. 94-106, March 1982.

[10] P. C. Godfrey, "The relationship between corporate philanthropy and shareholder wealth: A risk management perspective," The Academy of Management Review, vol. 30, pp. 777-798, October 2005.

[11] A. Gautier and A. C. Pache, "Research on corporate philanthropy: A review and assessment," $J$ Bus Ethics, vol. 126, pp. 343-369, November 2013.

[12] K. Dembek, P. Singh, and V. Bhakoo. (February 2015). Literature review of shared value: A theoretical concept or a management buzzword? Springer Link. [Online]. pp. 1-37. Available: http://link.springer.com

[13] S. Katrin and F. Kehrbach, "A three-dimensional framework to explore corporate sustainability activities in the mining industry: Current status and challenges ahead," Resources Policy, vol. 46, pp. 101-115, October 2014.

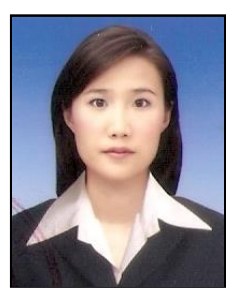

Chitphinan Charoenrungrueang was born on November 13, 1981 in Loei, Thailand. She received the master degree of corporate governance from Chulalongkorn University, Thailand in 2009, and the bachelor degree of information technology from Suranaree University of Technology, Thailand in 2003. Since 2010, she has been working in Ubon Ratchathani University. She is studying in doctor of philosophy program in management. Her research interests include corporate governance, corporate social responsibility, and creating shared value.

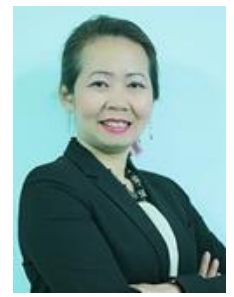

Mullika Sungsanit was born in Thailand on 19 February, 1972.

She received her Ph.D. in education (human resource development from University of Minnesota USA, in 2002, and M.B.A. in human resource management from Fairleigh Dickinson University, USA, in 1997, and B.A. in English from Srinakharinwirot University Mahasarakham Thailand, in 1995 .

She is currently a lecturer at Suranaree University of Technology (SUT) (Thailand). She is an InfoDev-WorldBank consultant and certified trainer, and a former manager of SUT Business Incubator and Intellectual Properties Management Office. She has more than 10 years of experience in entrepreneurship development. She had recently developed and delivered the training program for Women Entrepreneurs in the Mekong (Mekong Women Entrepreneurship Challenge Program: MWEC Program); i.e., Laos, Vietnam, and Cambodia, and for the Caribbean (Women Innovator Network in Caribbean: WINC, the GyB: Grow your Business Program). She is currently developing and testing a model for developing entrepreneurial skills and mindset for Science and Technology students for SUT. Her research interests are about entrepreneurship development, entrepreneurship education, innovation and organization performance, performance improvement, and managing a growing venture. 